\title{
The Constitutionality of Emergency Laws in Light of the Emerging Pandemic of the Coronavirus: A Comparative Study
}

\author{
ALI M. A. IQTAISH SHITAO WANG \\ School of law, Dalian Maritime University, Linghai Road, Dalian / zip code: 116026. -China
}

\begin{abstract}
The state of emergency is considered a serious and threatening situation that threatens public order in the whole country or part of it due to internal or external war, natural disasters or the spread of a pandemic, and in this study, we will specialize in researching the declared state of emergency in both Palestine and China in light of the Corona pandemic, Whereas, of course, the idea of the emergency law stems from the theories in constitutional law and the fact that many countries treat the state of emergency as a constitutional right granted to the executive in the form of a fortified constitutional decision.To declare a state of emergency, there are some important conditions. It is not permissible to declare a state of emergency without the availability of one of them, which involves the presence of a threat to the public order, The measures taken must be commensurate with the size of the risk, provided that the decree declaring the state of emergency includes the temporal and spatial scale, otherwise the decree is not considered void.The Palestinian legal system was distinguished by a precise definition of the steps to take the state of emergency with the support of the Palestinian Public Health Law and the supporting laws necessary to deal with epidemics, while the Chinese law was characterized by the existence of provisions in the constitutional law as well, but they were broad terms that needed more specificity regard to the competent authorities to extend The state of emergency and the percentage required to pass the decision to extend the state of emergency and other things were indicated in the study.This study also dealt with talk about the field effects on the executive authority, the legislature, and the judiciary in the event of an emergency, as this study examined the legal nature of the emergency law how to deal with both the Palestinian and Chinese legal systems and the extent to which the emergency law can be abolished if it is found not necessary.
\end{abstract}

Keywords: Constitutional Law, Administrative law, Palestinian Basic Law 2003, Chinese Constitution 1982, Public Health Law, Emergency Law, Martial Provisions, Coronavirus pandemic.

DOI: $10.7176 / \mathrm{JLPG} / 102-03$

Publication date:October $31^{\text {st }} 2020$

\section{Introduction:}

Since December 31, 2019, the world has been suffering from the spread of the Coronavirus, as China at the time reported to the World Health Organization the spread of pneumonia in Wuhan, Hubei Province, China, as all countries of the world admired how China imposed an unprecedented health belt (protected area). Prevents anyone from leaving) in Hubei Province, and sparks a wide debate among countries of the world about the possibilities and effectiveness of implementation. Cases have now spread to at least 4 continents, ${ }^{1}$ where medical and health measures imposed in all countries of the world, especially China, should be parallel to those measures, Some legal procedures constitute a guarantee of the application of health measures to be the pillar of their success, and that the size and bone of this epidemic, of course, requires a law equal to the same size, such as the constitution the law to form a protective shield for all preventive and curative health measures, and since constitutional law is a master Laws and the highest law in the state, it is natural that he take on this task.

Of course, the constitutional law, which regulates the work of the authorities in the state, was fully prepared for such emergency conditions, research that constitutes a pillar for the continuity of the state's institutions in the work by protecting the people from any emerging danger, whether visible, invisible, material or moral and for this most laws were created. Constitutions, including the Palestinian Basic Law 2003 and the Chinese Constitutional Law of 1982, are special laws that suit emergencies that the country may face and have been called emergency laws.

National laws differ among themselves, depending on the definition of a state of emergency, Each country has its standards that differ from it and are unique. For example, what is considered an emergency in Palestine may not be considered an emergency in China, Each country has its own economic, administrative, political, military, and social capabilities on which it can build its strategy, and each country has its criteria for determining what may pose a threat to that strategy.

We find that some jurists defined the state of emergency as: "temporary factors of a political nature in general, to varying degrees, that involve a grave and imminent danger, and threaten the organized existence of the nation, that is, the political and social system that consists of the state, which can be defined as a crisis affecting the

\footnotetext{
${ }^{1}$ Phelan, A. L., Katz, R., \& Gostin, L. O. (2020). The novel coronavirus originating in Wuhan, China: challenges for global health governance. Jama, 323(8), 709-710.
} 
population" As a whole ". It constitutes a threat to the organized existence of a society that forms the basis of the state ". 1

There are many studies, including some that emanate from the US Congress. He emphasized that the concept of the state of emergency is broad, and there is no unified concept for it, given that each country has the conditions that govern $\mathrm{it}^{2}$, Setting some general standards and characteristics, if available, the state of emergency must be declared and placed in four sections:

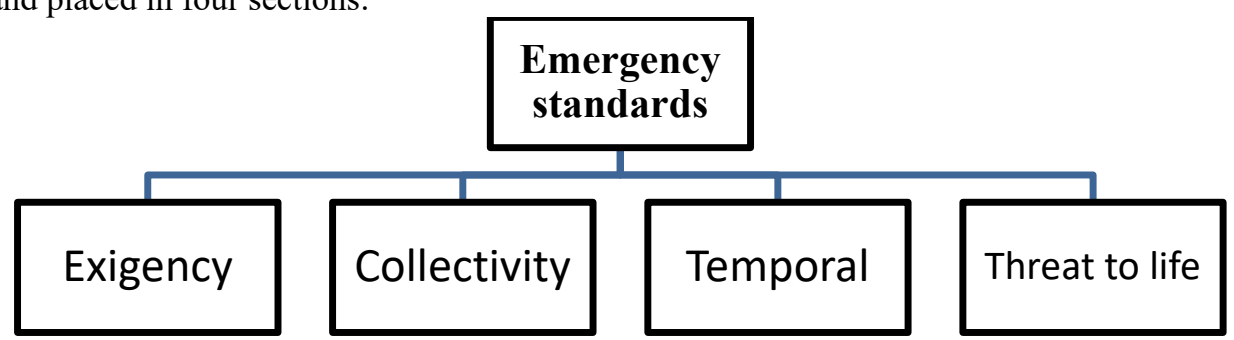

According to this opinion, the declaration of a state of emergency presupposes that there is a life-threatening necessity and that this collective threat threatens to paralyze the state's pillars, provided that the danger and the procedure are temporary.

Palestine has known many emergencies, such as the 1936 British Emergency Law during the British Mandate, ${ }^{3}$ Likewise, in the years (1968 and 1973), when the Israeli occupation government issued emergency instructions in Palestine, ${ }^{4}$ Several laws were also issued under the Palestinian government to combat many crises and disasters, including the financial consequences of which the government announced emergency budgets, as happened in the decision by the force of law for the year 2015, ${ }^{5}$ Also, the Palestinian government declared a state of emergency and issued emergency laws in 2006 for public health reasons and to counter the bird flu that spread at that time, ${ }^{6}$ the laws and regulations issued to confront the Corona pandemic in the year 2020 were and still are, until the moment, the most prominent of the public and specialists.

China is now advancing toward being a socialist country under the rule of law, with a socialist legal system with Chinese characteristics. In the course of the development of this system, China witnessed a series of emergencies: catastrophic floods, the SARS crisis, especially heavy pollution on the Songhua River, a major snow disaster in the South, the March 14 Incident in Lhasa, the great earthquake in Wenchuan, etc. In China, the term emergency refers to natural disasters, disasters arising from accidents, public health incidents, and public security incidents which occur suddenly and cause or could cause serious social harm and which require the adoption of urgent measures. Emergencies give rise to "states of emergency" that seem to be a no-go area for legal regulation. To deal with emergencies, a large number of normative documents have been formulated since 2004. The Master State Plan for Rapid Response to Public Emergencies and the Emergency Response Law are representative of these. These normative documents set up a unique framework and mechanism and stipulate special regulatory measures and modes of action that have been extensively applied in practice. ${ }^{7}$

\section{The difference between emergency law and martial law:}

The dispute between jurists arises over the relationship between martial law and the emergency law, as some jurists considered that both concepts are equal and there is no difference between the two terms and this difference does not exceed only a difference in the designation from one country to another. ${ }^{8}$

However, some researchers in this field have another opinion, and they considered that martial law differs from emergency laws, and they knew that martial law is: "Martial law is the law of military necessity in the actual presence of war. It is administered by the general of the army and is, in fact, his will. Of necessity it is arbitrary, but it must be obeyed."' At its essence, martial law is based on the concept of necessity, and provides a little limitation on the use of military power when circumstances require its imposition". 9

As I see, in my humble view, that the difference between the emergency law and martial law is not only a difference in naming, Rather, it is a legal misconception based on a flaw in the division of legal concepts. Of course, the defect in the concept of the legal term is the result of a misinterpretation and leads to an imbalance and improvisation in the legal performance later, and the risks are greater and more if this defect is within the

\footnotetext{
${ }^{1}$ Gross, O., \& Aoláin, F. N. (2006). Law in times of crisis: emergency powers in theory and practice (Vol. 46). Cambridge University Press.

${ }^{2}$ Hunter, N. D. (2017). The Law of emergencies: Public health and disaster management. Butterworth-Heinemann.

${ }^{3}$ The 1936 Emergency Law, era of the British Mandate for Palestine.

${ }^{4}$ Ordinance on Emergency Instructions 1945, 1968, 1973.

${ }^{5}$ Resolution No. (3) of 2015 regarding the emergency budget for the fiscal year 2015.

${ }^{6}$ Presidential Decree No. (17) of 2006 regarding the formation of a national emergency committee to deal with the spread of bird flu.

${ }^{7}$ Tao, M. (2011). Emergency law in China: its formation, present state and future. Social Sciences in China, 32(3), $104-119$.

${ }^{8}$ Vladeck, S. I. (2004). Emergency Power and the Militia Acts. Yale LJ, 114, 149.

${ }^{9}$ Feldman, W. (2005). Theories of Emergency Powers: A Comparative Analysis of American Martial Law and the French State of Siege. Cornell Int'l LJ, 38, 1021
} 
interpretation of a constitutional legal text, Where I see that the term state of emergency includes martial law and other exceptional laws that include under the name of the state of emergency or the law of emergency or other names such as the Defense Law for example in Jordan, and I concluded after reading some constitutions that the Palestinian Constitution of 2003 and the Chinese 1982 did not address a clear and specific interpretation This issue is in contrast to what was distinguished by the Jordanian constitutional law of $1952,{ }^{1}$ which clarified that the state of emergency is a state of necessity and an exception that requires as a start and as a first working step for issuing the defense law. The comprehensiveness of all emergency law (defense law) and martial law, but the difference between emergency law and customary law is that the latter (martial law) is more dangerous than the first (defense law or emergency law), As shown in the illustration below:

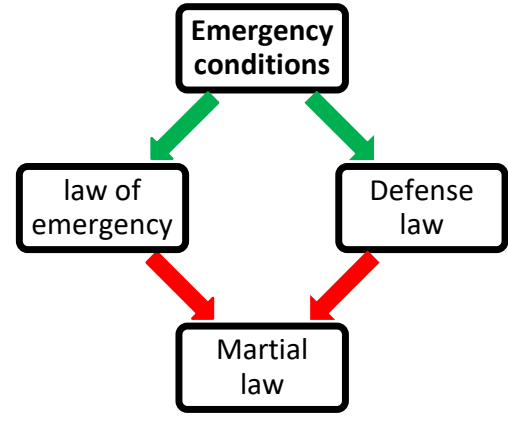

\section{Legal rules regulating emergency laws:}

The legal rules regulating emergency laws differ from one country to another, but there is almost unanimity among countries that the constitutional law is the internal organizer of emergency laws, and international agreements are the external organizer of emergency laws, and this is what we will explain in the following:

\section{Internal legal regulation of the state of emergency:}

The Palestinian Basic Law of 2003 and its amendments, which is the Constitutional Law of Palestine, is the regulator of emergency laws. Chapter Seven of the law deals with articles (110-114) in detail how to issue emergency laws in Palestine, The law gave the head of state the authority to issue a 30-day emergency law in cases of severe threats to national security, but the extension falls within the authority of Parliament and Parliament can review these measures, provided that freedoms are safeguarded. ${ }^{2}$

But this, was not followed in light of the current conditions that Palestine suffers from under the Corona epidemic, and some constitutional provisions were violated, and this is not because of the government's desire to violate it, but because of the suspension of the Palestinian parliament since 2007, because of the arrest of the occupying Power, most members of Parliament Palestinian. Since 2007, the President has passed the Emergency Law to address the Corona Virus in its constitutional form, but it has not been extended through Parliament as stipulated in the Constitution, This, in my opinion, is not a constitutional defect, because the state of emergency does not wait for the holding of parliamentary elections to enable Parliament to take its urgent decision to issue the emergency law, The Presidency has done well in taking all preventive and remedial measures to combat Coronavirus accordance with the constitutional powers granted to the president accordance with Article (43) of the Palestinian Basic Law 2003.

The Basic Law was not the only law to address the issue of the emergency law, We find that the Palestinian Public Health Law of 2004 dealt in detail with a full explanation of the state of emergency in the face of the epidemic and did not neglect anything in my view, because I see it as an integrated law, as the Public Health Law of 2004 devoted a full chapter to articles (9-15), to detail and explain the measures Legal and health response to epidemics. ${ }^{3}$

The Palestinian Ministry of Health has completed all legal measures to combat the Corona epidemic, by issuing a decision by the Palestinian President, ${ }^{4}$ with the force of law, as a researcher and legal follower of the legal situation in Palestine, have not found any legal deficiencies in the work of the Palestinian Ministry of Health

\footnotetext{
1 Jordanian Defense Law.

${ }^{2}$ Palestinian Basic Law (2003) and its amendments, For more: Article (110-114) "1- When there is a threat to national security due to war invasion, armed insurrection, or natural disaster, a state of emergency may be declared by decree of the President of the National Authority for a period not exceeding thirty days. 2- The state of emergency may be extended for another thirty days after the approval of the Palestinian Legislative Council by a two-thirds majority of its members. 3- The decree declaring a state of emergency must clearly state the objective, the area it covers and the time period. 4- The Legislative Council has the right to review all or some of the procedures and measures taken during the state of emergency at the first meeting with the Council after declaring the state of emergency or in the extension session, whichever is earlier and conduct the necessary interrogation in this regard"....

${ }^{3}$ Palestinian Public Health Law 2004.

${ }^{4}$ Decision of Law No. (17) of 2020 regarding preventive public health and safety measures and their contravention In the event of an emergency.
} 
and that the deficiency was a technical deficiency caused by The global need for epidemic control equipment, but this friendly international cooperation between Palestine as China contributed directly to reducing this technical deficiency.

No legal vacuum was mentioned in the work of the Ministry of Health. The Ministry of Health's work to confront the Corona epidemic was based on appropriate laws and regulations, where the obvious defect is a technical defect related to technical capabilities and the Ministry of Health's willingness to confront this danger, and of course, the Republic of China had a large and clear role in reducing it.

All laws in Palestine have cooperated to form an emergency legal system to confront the Corona Virus Regulations, including the decree against cybercrime, Also have a prominent and clear role in fighting electronic rumors, fortifying society's immunity, strengthening his resolve, and raising his morale to be able to withstand legal procedures, so have an educational, preventive, and punitive task. ${ }^{1}$

As for the People's Republic of China and its legal system, which differs from the legal system in Palestine for several factors, including ideology, demography and geography, the Chinese Constitutional Law of 1982 and its amendments on the state of emergency, and the necessity of declaring a state of emergency in exceptional circumstances as previously explained, However, the prominent difference between the Palestinian and Chinese legal systems in this matter is that the Chinese legal system linked the authority to declare a state of emergency to the logic of geography, making each geographical region according to the administrative divisions, Where the Chinese constitution stipulated the power to declare a state of emergency in three different articles, the law gave the Chinese constitution the power to declare a state of emergency for the president in Article (80), It gave the President of the Republic the power to declare a state of emergency, However Article (67) of the Standing Committee of the National People's Congress granted a number of powers, including deciding to enter the state of emergency in all parts of the country or in provinces, autonomous regions or municipalities directly affiliated with the central government, also the (Paragraph 16 of Article 89) granted the State Council a number of functions and powers, including the authority to declare a state of emergency in accordance with the provisions of the law, to decide on entering the state of emergency in parts of provinces, autonomous regions and municipalities directly under the central government; This is only for areas under central rule. ${ }^{2}$

Although the Chinese constitution deals with the text of the state of emergency and the sharing of powers between state organs according to administrative divisions, it was not clear about the percentages of voting to pass the emergency law, because the constitutional law did not specify any specific proportion of the emergency law to be announced, with respect the powers of the Standing Committee of the National People's Congress, Where I see that this is a deficiency that must be overcome and amended as the Palestinian Basic Law did when it linked the extension of the state of emergency with the approval of two-thirds of the members of Parliament, so that the homeland is not held hostage by a certain group that wants to harm it, either intentionally or by misjudgment and management.

At present, China has not yet had a basic law comprehensively standardizing the work of disaster prevention and mitigation, and the law system for disaster management is not complete and uniformed. China is due to complete the existing laws and regulations as soon as possible, and establish a comprehensive legal system for disaster prevention and mitigation, and then promulgate the disaster basic law, as to determine, in form of laws, ${ }^{3}$ and all the laws in china it individual laws as :"Law of the People's Republic of China on Practicing Physicians", "Regulations concerning the Administration of Medical Institutions" and the rules for their implementation, "Administrative Measures for Nurses", and "People Law" "Republic of China on Maternal and Child Health Care" and the measures for their implementation, The "People's Obligations of the People's Republic of China" the Constitution of the Blood Donation Law and other laws and regulations basic principles of the Health Law, the basic principles of health administrative law and the principles of the administrative legal system, refer to the basic spirit and guidelines of the health legal system that guide and restrict health administrative legislation and its implementation in all Over the health administrative law norms and health administrative relations, In order to coordinate the province's epidemic prevention and control and the overall situation of economic and social development, speed up the establishment of an economic and social operation order compatible with epidemic prevention and control, in accordance with relevant national laws and regulations and the prevention and control of new coronary pneumonia epidemic, For this purpose," Article 69 of the Emergency Response Law enacted in 2007 clearly distinguishes between the state of emergency response and the state of emergency. At this point, China's emergency law has successively developed three states of exception: the state of war, the state of emergency and the state of emergency response, in descending order of the range and seriousness of the emergency. China's system of emergency law consists of the laws, regulations and emergency plans that govern these three states, as shown in the following table., It is extremely important to unveil the ambiguity related to this

\footnotetext{
${ }^{1}$ Resolution No. (10) of 2018 on cybercrime.

${ }^{2}$ Chinese Constitution law 1982.

${ }^{3}$ Ang, H. (2010, May). China's Emergency Management Mechanisms for Disaster Prevention and Mitigation. In 2010 International Conference on E-Business and E-Government (pp. 2403-2407). IEEE.
} 
matter, ${ }^{1}$ according to the following:

\begin{tabular}{|c|c|c|c|c|}
\hline $\begin{array}{l}\text { Type of state } \\
\text { of exception }\end{array}$ & Origins of norm & Causes of emergency & $\begin{array}{l}\text { Decision-making } \\
\text { body }\end{array}$ & $\begin{array}{l}\text { Special control } \\
\text { bodies }\end{array}$ \\
\hline State of war & $\begin{array}{l}\text { Constitution; National } \\
\text { Defense Law; National } \\
\text { Defense Mobilization } \\
\text { Law; military regulations }\end{array}$ & $\begin{array}{l}\text { Foreign aggression, } \\
\text { armed subversion, } \\
\text { etc. }\end{array}$ & $\begin{array}{l}\text { The National } \\
\text { People's Congress } \\
\text { (when not in } \\
\text { session, the } \\
\text { NPC Standing } \\
\text { Committee) }\end{array}$ & $\begin{array}{l}\text { Armed forces } \\
\text { (army, armed } \\
\text { police and militia) }\end{array}$ \\
\hline $\begin{array}{l}\text { State of } \\
\text { emergency }\end{array}$ & $\begin{array}{l}\text { Constitution; Martial } \\
\text { Law; Emergency } \\
\text { Response Law }\end{array}$ & $\begin{array}{l}\text { Disturbance, } \\
\text { rebellion or } \\
\text { serious riot, major } \\
\text { unforeseen incidents }\end{array}$ & $\begin{array}{l}\text { NPC Standing } \\
\text { Committee; State } \\
\text { Council }\end{array}$ & $\begin{array}{l}\text { Police and Armed } \\
\text { Police (assisted } \\
\text { by the PLA when } \\
\text { necessary) }\end{array}$ \\
\hline $\begin{array}{l}\text { State of } \\
\text { emergency } \\
\text { response }\end{array}$ & $\begin{array}{l}\text { Emergency Response } \\
\text { Law; emergency plans of } \\
\text { government, government } \\
\text { departments and military } \\
\text { authorities, etc. }\end{array}$ & $\begin{array}{l}\text { Natural disaster; } \\
\text { disaster caused by } \\
\text { accident; unforeseen } \\
\text { public health } \\
\text { incident; incident } \\
\text { affecting public } \\
\text { security }\end{array}$ & $\begin{array}{l}\text { Governments } \\
\text { and government } \\
\text { departments at } \\
\text { various levels }\end{array}$ & $\begin{array}{l}\text { Various } \\
\text { government } \\
\text { departments; armed } \\
\text { forces }\end{array}$ \\
\hline
\end{tabular}

However, as we explained earlier, the emergency response law is a difference between the state of emergency and the law of response, as well as a difference between their procedures. Divide the emergency response procedures Also, the State Council has vigorously promoted the development of a national emergency response system: the various emergency plans represented by the Master State Plan for Rapid Response to Public Emergencies make up a four-level early warning and response mechanism, with each level of response triggering different emergency response measures, thus constituting four corresponding "states of emergency response", According to the scope of impact and the degree of harm of public health emergencies, emergency response to public health emergencies is divided into four levels: Level I, level II, level III, and Level IV, as follows:

\section{Level I response}

In the event of a particularly significant public health emergency, the Provincial Headquarters organizes and coordinates emergency response work within its administrative area in accordance with the State Council's decision and deployment and unified command.

\section{Level II response}

When a major public health emergency occurs, the provincial headquarters immediately organizes the analysis and judgment of the members and experts of the headquarters to conduct a comprehensive assessment of the impact of public health emergencies and their development trends. The provincial people's government decides to initiate a level II emergency response All relevant units issue orders to start relevant emergency procedures. The Provincial Headquarters immediately dispatched a working group to the place where the incident occurred to carry out emergency response work and quickly reported the relevant situation to the State Council and its relevant departments. In accordance with the unified deployment of the provincial headquarters, the people's governments at all levels in the place where the incident occurred organized and coordinated the emergency command institutions and relevant member units of public health emergencies at their respective levels to carry out emergency response efforts.

\section{Level III response}

In the event of a major public health emergency, the prefecture-level public health emergency command agency that is directly under the control of the county (city, district) directly organizes the members and experts of each unit to analyze and judge the impact and development trend of the event. For a comprehensive assessment, the prefecture-level listed people's government decides to initiate a level III emergency response and issues an order to initiate relevant emergency procedures to all relevant units. When necessary, the Provincial Health and Family Planning Commission dispatched a working group to the place where the incident occurred, instructing the prefecture-level public health emergency command institutions that are directly under the control of counties (cities and districts) to do relevant emergency response work.

\section{Level IV response}

When a general public health emergency occurs, the county (city, district) (excluding counties (cities, districts) directly managed by the province (the same applies hereinafter)) public health emergency response command organization immediately organizes the analysis and judgment of the members and experts of each unit. The impact of the incident and its development trend will be comprehensively evaluated, and the county-level people's government will decide to initiate a level IV emergency response and issue orders to all relevant units to start the relevant emergency procedures. When necessary, the prefecture-level public health and family planning department dispatched a working group to the place where the incident occurred and guided the county (city,

\footnotetext{
${ }^{1}$ Tao, M. (2011). Emergency law in China, Previous reference.
} 
district) emergency command institution for public health emergencies to do related emergency response work. ${ }^{1}$ The principle of emergency response in health administration is an important part of the modern administrative legal system. It refers to the need for national health, social order, the safety of people's lives, or other public interests in certain special emergencies. Specific measures based on or in conflict with the law, During the operation of the country and society, some emergencies inevitably occur, such as wars, important epidemics, and the spread of new diseases. The occurrence of these situations may threaten the security of the country, the personal safety of citizens, and good social order. In the case of normal constitutional government and legal systems that are difficult to operate, the necessary emergency measures taken by the health administrative agencies should be considered effective even if there is no legal provision or conflict with the law, ${ }^{2}$ but In my view, the existence of administrative instructions and regulations is not considered sufficient, so it is better to have a basis for these regulations. I recommend that there is a public health law in China on which all procedures are based.

\section{International legal regulation of the state of emergency:}

International laws have had a prominent role in pointing to the importance of the state of emergency and making national or domestic laws take this seriously, This was certainly stated in the International Covenant on Civil and Political Rights, which in Article (4/1) states that: "In the time of public emergency which threatens the life of the nation and the existence of which is officially proclaimed, the States Parties to the present Covenant may take measures derogating from their obligations under the present Covenant to the extent strictly required by the exigencies of the situation, provided that such measures are not inconsistent with their other obligations under international law and do not involve discrimination solely on the ground of race, color, sex, language, religion or social origin". 3

Some continent-wide agreements also take into account the state of emergency, for example, the 1978 American Human Rights Convention, As this agreement stipulated the importance and privacy of the state of emergency, an exceptional circumstance, and Article 27 of it stipulated: "1. In time of war, public danger, or other emergencies that threatens the independence or security of a State Party, it may take measures derogating from its obligations under the present Convention to the extent and for the period strictly required by the exigencies of the situation, provided that such measures are not inconsistent with its other obligations under international law and do not involve discrimination on the ground of race, color, sex, language, religion, or social origin. 2. The foregoing provision does not authorize any suspension of the following articles: Article 3 (Right to Juridical Personality), Article 4 (Right to Life), Article 5 (Right to Humane Treatment), Article 6 (Freedom from Slavery), Article 9 (Freedom from Ex Post Facto Laws), Article 12 (Freedom of Conscience and Religion), Article 17 (Rights of the Family), Article 18 (Right to a Name), Article 19 (Rights of the Child), Article 20 (Right to Nationality), and Article 23 (Right to Participate in Government), or of the judicial guarantees essential for the protection of such rights. 3. Any State Party availing itself of the right of suspension shall immediately inform the other States Parties, through the Secretary-General of the Organization of American States, of the provisions the application of which it has suspended, the reasons that gave rise to the suspension, and the date set for the termination of such suspension". 4

In my view, in light of the existence of international agreements stipulated by the Palestinian Basic Law that they must be respected, if I consider it necessary to have a special regional agreement in the Asian continent to unify efforts and support regional efforts to confront any potential danger, which certainly contributes to strengthening international efforts, If the efforts made at the level of the state, the region and the continent are the same, then this will lead to the strengthening and strengthening of collective international action to confront any danger.

\section{The effects of the emergency declaration:}

The presence of the state of emergency will have tangible effects that directly affect the lives and freedoms of citizens, based on the discretionary powers that the law confers on the executive, legislative, and judicial authority, contrary to what some belief is confined only to the executive, This is what we will explain as follows

\section{Field effects (executive authority):}

As stipulated in the Palestinian Basic Law, the executive authority is the main originator of the state of emergency, according to a decision by the president, and it follows that the Palestinian security services assume full control over the aspects of life through deployment in the field. This is what the Prime Minister Decision No. (3) of 2020 stipulated: " The national security forces and the police, in cooperation with the rest of the security forces, shall

\footnotetext{
${ }^{1}$ http://www.tynews.com.cn/system/2020/03/10/030191517.shtml, access date: 15/6/2020.

${ }^{2}$ Gostin, L. O., Viswanathan, K., Altevogt, B. M., \& Hanfling, D. (Eds.). (2012). Crisis Standards of Care: A Systems Framework for Catastrophic Disaster Response: Volume 1: Introduction and CSC Framework (Vol. 3). National Academies Press.

${ }^{3}$ International Covenant on Civil and Political Rights 1966.

${ }^{4}$ American Convention on Human Rights 1978.
} 
assume the task of implementing the provisions of this decision, by deploying their forces inside cities and villages and controlling their entrances, in order to maintain Public security and public health ". 1

This is, of course, what has been done in China in past and present crises in China, where the Chinese army and police have played a large roles a study of the response network in the Lushun Earthquake shows that the firefighting department ranked highest in terms of centrality, followed by the armed police and the armed forces. ${ }^{2}$

\section{The state of emergency also authorizes the government}

to take some measures that restrict the movement of citizens and goods, the use of public transportation, land, sea, and air travel, and postal correspondence, define specific times for shopping and use of public facilities and define health measures in cooperation with the Ministry of Health. ${ }^{3}$

In these measures, the Republic of China is one of the first countries to take all precautionary measures. He declared the cities in which the epidemic has been closed and stopped all public transportation and air traffic, and closed all shops and all necessary and necessary measures to control the epidemic, and announced many punitive measures in the event of a violation of these procedures. At the tangible or intangible level, whether through breaching the curfew, for example, or leaking information about the injured and preparing them and their cases, or spreading rumors in order to spread terror among citizens, all this is based on the provisions of Law of the People's Republic of China on Prevention and Treatment of Infectious Diseases (2013 Amendment). ${ }^{4}$

\section{Legislative effects (Legislative Authority)}

We also know that the legislative authority is one of the most important pillars of the legal system, as the Palestinian Basic Law did not provide for the disruption of legislative powers, But in reality curtailed these powers, especially since the Basic Law gave the president in a state of emergency the power to pass emergency legislation, but he kept Parliament in working condition, However, the current situation in Palestine in the absence of the parliament, the powers of the legislative authority are transferred to the president in an emergency and exceptional manner, such as the authority to extend, as stated in Presidential Decree No. 3 of $2020 .^{5}$

It should also be noted that the validity of the legislation is not limited to issuing new legislation, or amending previous laws, but also extends to the abolition of temporary suspension of the laws in effect in normal circumstances such as: disrupting the law of weapons and ammunition, which grants the right to acquire weapons and ammunition.

In China, the situation is somewhat different, as the Emergency Response Law already exists, However, the government is responsible for preparing plans based on this law, ensuring the rights of citizens to violate, and protecting their constitutional rights, in a manner consistent with this emergency, and is also responsible for the laws and regulations that have been issued to manage and respond to the state of emergency, as the Chinese government enjoys With absolute authority to deal with and respond to emergencies. ${ }^{6}$

From my point of view, there is a slight difference between the Palestinian and Chinese legal system in how to deal with the state of emergency as Chinese law gave the government absolute authority to deal with the state of emergency, while Palestinian basic law gave the executive authority relative authority, as I support what Palestinian law has adopted as There must be legislative oversight of the work of the executive branch so that the executive does not invade and abuse the powers.

\section{Influencing the judiciary:}

Changing the competent authorities in issuing legislation and granting the executive authority exceptional powers, certainly leads to influence the judicial authorities, but this effect does not affect the spatial, temporal or personal jurisdiction, in emergency cases before the judiciary, such as a decision that the Palestinian government represented by the Prime Minister adheres to the principle Preservation and judicial procedures are the same. The decision of the Palestinian government stipulated the following: 1. The public prosecution, the military prosecution, and law enforcement agencies that have the capacity of judicial seizure, each in its field of competence, are concerned with following the enforcement of the provisions of this law, decisions, instructions, and measures emanating from it. 2 . The consequences of violating the provisions of this law and the decisions, instructions, and measures emanating from it. $^{7}$

\footnotetext{
${ }^{1}$ Palestinian Prime Minister Decision No. (3) of 2020, 25/3/2020.

${ }^{2}$ Haibo, Z., \& Xing, T. (2016). Structural change in China's emergency management: theoretical generalizations. Social Sciences in China, 37(2), 77-98

${ }^{3}$ Prime Minister Decision No. (2) of 2020 "Emergency", 25/3/2020.

${ }^{4}$ Law of the People's Republic of China on Prevention and Treatment of Infectious Diseases (2013 Amendment).

${ }^{5}$ Presidential Decree No. 3 of 2020, 20/4/2020.

6温志强, \& 郝雅立. (2017). 《突发事件应对法》 实践十年: 成绩, 问题与未来展望—中国《突发事件应对法》 实践十年 (20072017). 江西财经大学学报, (5), 124-131.

${ }^{7}$ Resolution No. (7) of 2020 About the emergency Palestine, 25/3/2020.
} 
It is not very different in China in terms of the judicial system in case of an emergency. Procedures and jurisdiction continue, but with a special kind of sanctions, The government under its jurisdiction shall, in accordance with the law, take compulsory measures to restrict all kinds of the congregation, and ensure the supply of living resources. They will also ensure the sufficient supply of masks, disinfectants, and other protective articles on the market, and standardize the market order. The strengthening of public health surveillance, hygiene knowledge publicity, and monitoring of public places and key groups is required. Comprehensive medical institutions and some specialized hospitals should be prepared to accept COVID-19 patients to ensure that severe and critical cases can be differentiated, diagnosed, and effectively treated in time. The health administration departments, public health departments, and medical institutions at all (province, city, county, district, township, and street) levels, and social organizations shall function in epidemic prevention and control and provide guidance for patients and close contact families for disease prevention, it is possible to manage residents of each jurisdiction systematically to monitor the epidemic's advancement, promote epidemic information, and educate residents on healthy behavior. The community is the public's direct recipient, processer, and promoter of travel history reports to high-risk epidemic regions. ${ }^{1}$

\section{Administrative judiciary oversight of the emergency law}

The declaration of a state of emergency represents the implementation of the emergency law and that the executive has exclusive powers, and this, of course, constitutes a departure from the normal circumstances of the importance of declaring a state of emergency and its gravity to the rights of individuals, It is considered self-evident that the common people complain about the diminishing of their basic freedoms in the event of declaring a state of emergency, especially under the pretext that it is not necessary to declare a state of emergency. ${ }^{2}$

The legal trends differed in this issue, Some researchers believe that declaring the state of the emergency is an administrative decision like any other administrative decisions issued by the executive authority, which are competent to consider the Court of Justice or the Administrative Court, ${ }^{3}$ Knowing the legal nature of the emergency law is of great importance, as this defines the courts and procedures and eliminates differences about the nature of this emergency law, Whereas the Palestinian legal system considered the decree of the declaration of emergency to be a fortified decree and it is not permissible to appeal it permanently, but it approved the appeals for human rights violations that arise from it before the regular judiciary. ${ }^{4}$

As for the Chinese legal system, the matter is different. The Chinese constitution was not clear enough about the legal nature of the decision to declare a state of emergency, The constitutional law did not consider that the emergency law is like any other administrative decision, but rather considered it as a decision that stems from constitutional powers, but this decision is not immune but rather amending, it is subject to increase or decrease in its articles, or its cancellation and this authority was granted NPC according to(Article 62 Paragraph 11 ) of the Chinese constitution, but this is of course what is in effect in China, but this article needs more explanation whether or not the emergency law falls within the understanding of that article or not. ${ }^{5}$

I think that it is better to have judicial oversight of emergency laws and out of the scope of legislative supervision only as it exists in China, and I prefer that Palestinian and Chinese law provides for the right of the administrative judiciary to adjudicate lawsuits related to repealing the emergency law itself so that its immunity is not for any A decision, given that those in charge of the executive are human beings may fall into miscalculation and error.

\section{Conclusion}

Through our study of the emergency laws, we find that declaring a state of emergency according to the conditions of each country was necessary during the Coronavirus pandemic, but it was not welcomed by all parts of society as it severely restricted rights and freedoms and had a great impact on crippling the economy and reducing social relations in a way Large, of course, is not a mistake, because the health security in the Corona pandemic is incompatible with public freedoms, but these measures, in my opinion, were not to diminish the freedoms as much as they came in order to protect their permanence, Whereas, the effects were not limited to the work of the executive authority, which is the first line of defense against the Coronavirus represented by the police and health services but extends to the powers of both the legislative and judicial authority as well, Of course, this study leads us to many findings and recommendations as follows:

\footnotetext{
${ }^{1}$ Wei, L., Sha, Z., Wang, Y., Zhang, G., Jia, H., Zhou, S., ... \& Wu, Q. (2020). Willingness and Cognition Toward Reporting Travel History to High-Risk Coronavirus Disease 2019 Epidemic Regions Among The Chinese Public: A Cross-Sectional Study.

${ }^{2}$ Fitzpatrick, J. (1994). Human rights in crisis: the international system for protecting rights during states of emergency (Vol. 19). University of Pennsylvania Press.

${ }^{3}$ Ferejohn, J., \& Pasquino, P. (2004). The law of the exception: A typology of emergency powers. International Journal of Constitutional Law, 2(2), 210-239.

${ }^{4}$ Palestinian Basic Law 2003 and its amendments, Article (32).

${ }^{5}$ Chinese constitutional law 1982, Article(62/11).
} 


\section{The results :}

- Among the most prominent exceptional systems used to cope with the state of emergency, the emergency laws as it is in the Chinese and Palestinian system, as well as martial law and defense laws.

- The Palestinian and Chinese constitutional system made it possible to declare a state of emergency in the event of a real and significant threat to the state.

- The danger that justifies declaring a state of emergency may be external war, internal war, or natural and abnormal disasters that the public authority cannot face with ordinary laws and procedures.

- The legal organization of the state of emergencies differs from one country to another, as are the methods of its application. The legislation of the state of emergencies indicates the reason for its declaration and specifies the period of validity and the regions in which it is applied.

- There is no public health law in the Chinese legal system, unlike the Palestinian legal system. Rather, there is a set of laws in the system that constitute as a whole a defense system in an emergency, the most prominent of which is the Emergency Respon4se Law, which divides the response into four levels.

\section{Recommendations:}

- I recommend that both the Palestinian and Chinese legislators provide more clarification on the emergency law, whether in the body of the law or through interpretive opinions from the competent courts.

- It is also necessary to stipulate, whether in international and regional charters or state constitutions, the limits of the executive authority and control of its performance, as is the case in the Palestinian Basic Law, which gave Parliament the power to control the extension of the emergency law, where there should be also judicial oversight On issuing the law itself for the first time, and it is not limited to monitoring the extension, because this represents more guarantee human rights.

- I recommend that each of the competent authorities in the Palestinian legal systems, as well as the Chinese, should have interpretation and clarification on martial law and emergency laws.

- I recommend the Chinese legal legislator to place a specific percentage specifically in the Chinese People's Assembly to amend the emergency law as mentioned in Article (11/62), just as the Palestinian Basic Law did by setting the ratio of two-thirds as a condition. To extend the emergency.

- I recommend the Palestinian and Chinese legislators to distinguish between the reasons for declaring a state of emergency. I prefer that the Palestinian legislator resort to the simple majority in the event of declaring a state of emergency in the event of epidemics and natural disasters while maintaining a twothirds majority in the event of declaring a state of emergency due to wars, for the speed of the required procedure in the case of epidemics and natural disasters from the state of war, especially since Palestine is in a state of war Constant assault and slander by the Zionist enemy.

- Chinese legal system in preparing a special integrated law in the so-called emergency response law, which is divided into four sections, and I recommend that the Palestinian legislator follow what the Chinese legislator has taken in this field, to prepare plans for all future scenarios for emergencies.

\section{References :}

1.American Convention on Human Rights 1978.

2.Ang, H. (2010, May). China's Emergency Management Mechanisms for Disaster Prevention and Mitigation. In 2010 International Conference on E-Business and E-Government (pp. 2403-2407). IEEE.

3.Chinese Constitution law 1982.

4.Decision of Law No. (17) of 2020 regarding preventive public health and safety measures and their contravention In the event of an emergency.

5.Feldman, W. (2005). Theories of Emergency Powers: A Comparative Analysis of American Martial Law and the French State of Siege. Cornell Int'l LJ, 38, 1021.

6.Ferejohn, J., \& Pasquino, P. (2004). The law of the exception: A typology of emergency powers. International Journal of Constitutional Law, 2(2), 210-239.

7.Fitzpatrick, J. (1994). Human rights in crisis: the international system for protecting rights during states of emergency (Vol. 19). University of Pennsylvania Press.

8.Gross, O., \& Aoláin, F. N. (2006). Law in times of crisis: emergency powers in theory and practice (Vol. 46). Cambridge University Press.

9.Haibo, Z., \& Xing, T. (2016). Structural change in China's emergency management: theoretical generalizations. Social Sciences in China, 37(2), 77-98.

10.Hunter, N. D. (2017). The Law of emergencies: Public health and disaster management. ButterworthHeinemann.

11.International Covenant on Civil and Political Rights 1966.

12.Law of the People's Republic of China on Prevention and Treatment of Infectious Diseases(2013 Amendment). 
13.Ordinance on Emergency Instructions 1945, 1968, 1973.

14.Palestinian Basic Law (2003) and its amendments.

15.Palestinian Prime Minister Decision No. (3) of 2020, 25/3/2020.

16.Palestinian Public Health Law 2004.

17.Phelan, A. L., Katz, R., \& Gostin, L. O. (2020). The novel coronavirus originating in Wuhan, China.

18.Presidential Decree No. 3 of 2020, 20/4/2020.

19.Presidential Decree No. (17) of 2006 regarding the formation of a national emergency committee to deal with the spread of bird flu.

20.Prime Minister Decision No. (2) of 2020 "Emergency", 25/3/2020.

21.Resolution No. (3) of 2015 regarding the emergency budget for the fiscal year 2015.

22.Resolution No. (7) of 2020 About the emergency Palestine, 25/3/2020.

23.Resolution No. (10) of 2018 on cybercrime.

24.Tao, M. (2011). Emergency law in China: its formation, present state, and future. Social Sciences in China, 32(3), 104-119.

25.The 1936 Emergency Law, an era of the British Mandate for Palestine.

26.Vladeck, S. I. (2004). Emergency Power and the Militia Acts. Yale LJ, 114, 149.

27.Wei, L., Sha, Z., Wang, Y., Zhang, G., Jia, H., Zhou, S., ... \& Wu, Q. (2020). Willingness and Cognition Toward Reporting Travel History to High-Risk Coronavirus Disease 2019 Epidemic Regions Among The Chinese Public: A Cross-Sectional Study.

28. 温志强, \& 郝雅立. (2017). 《突发事件应对法》 实践十年: 成绩, 问题与未来展望一一国《突发事件 应对法》 实践十年 (2007-2017). 江西财经大学学报, (5), 124-131.

29. http://www.tynews.com.cn/system/2020/03/10/030191517.shtml, access date: 15/6/2020. 